PROFILES

The State University of New York at Buffalo in April chose SAKTIDAS ROY as director of its university libraries. Roy had held the title, on an interim basis, since the previous June. His new appointment follows a demonstration of effective leadership, convincing to the university administration and to the library staff.

Roy has not taken the conventional route to the top. He has zigzagged between India and the U.S. and between Harvard and other American universities. He was recruited

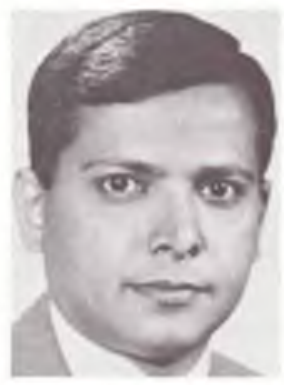

Sakfidas Hoy into librarianship in 1954 by the United States Information Library in Calcutta, where he also did his undergraduate work and earned a diploma in library science.

In 1960, ready for American experience, he obtained an "intern" position in Baker Library at

\section{ILL in Mexico}

A brief news note to let your readers be aware of an irresponsible institution using interlibrary loans in a manner that has eliminated Mexican colleges and universities as a viable recipient for using Oregon library resources:

The Southern Oregon State College Library, along with the Oregon State University Lihrary, have, over the past few years, lost several hooks that were loaned to the Technologico Corteza in Mexico City. The books were loaned in response to a standard interlibrary loan form request from that institute. Nothing has been returned and no reply has been forthcoming from repeated requests for information, settlement, or payment.

I recommend that all ARL libraries stop service to this institute and apply whatever pressure possible to stop the abuse of the interlibrary loan network, or it will lead to the end of the interlibrary loans system, particularly to foreign institutions.

Richard E. Moore

Library Director

Southern Oregon State College. the Harvard Business School and enrolled in an MLS program at Simmons College. He laid a firn basis for a future career at Simmons and at Baker Library, where he was soon promoted and aided in computerizing the processing of serials. In 1965 he was offered a position in India and returned there to serve as librarian of the American Studies Research Center in Hyderabad for a year and as chief librarian in the American Libraries Bonk Procurement Center in Delhi for another year.

Restlessly, he returned to this country as assistant acquisitions librarian at the University of California, Santa Cruz, and then again to Harvard as head of the Serials Records Division in the College Library. In 1972 he hecame head of the Preparations Division at the Virginia Polytechnic Institute and State University, Blacksburg, and in 1973 assistant director for technical services at Buffalo. Recent years at Buffalo, as elsewhere, have been marked by multiple changes and difficulties. Through these Roy has kept a steady course, worked harder than anyone else, supported and eamed the confidence of the staff, and emerged as a mature, skilled, and successful librarian, with many years of achievement ahead of him.-Laurence J. Kipp, Librarian, Baker Library, Harvard Business School.

HWA-WEI LEE has accepted the position as director of Ohio University Libraries in Athens, Ohio, effective August 1, 1978. In 1955, Lee received his B.A. from National Taiwan Normal University in Taipei. In 1959, he earned an M.A. in education from the University of Pittsburgh and in 1961, an M.L.S. from Carnegie Mellon. He received his Ph.D. in the foundations of education and library science at the University of Pittsburgh in 1964 .

He has been the associate director of $\mathrm{li}$ -

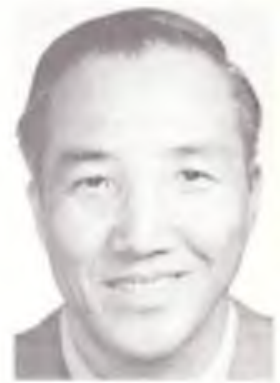

Hua-Wei Lee braries at Colorado State in Fort Collins since 1975. Before that, he held administrative posts with the Asian Institute of Technology's Library and Information Center while also serving as an associate faculty member of Chulalong Kom University in Bangkok.

Lee has been active in a variety of organizations, and his membership in ALA includes the ACRL and LAD divisions. His varied interests 


\section{"Literacy is not an end in itself. It is a fundamental human right."}

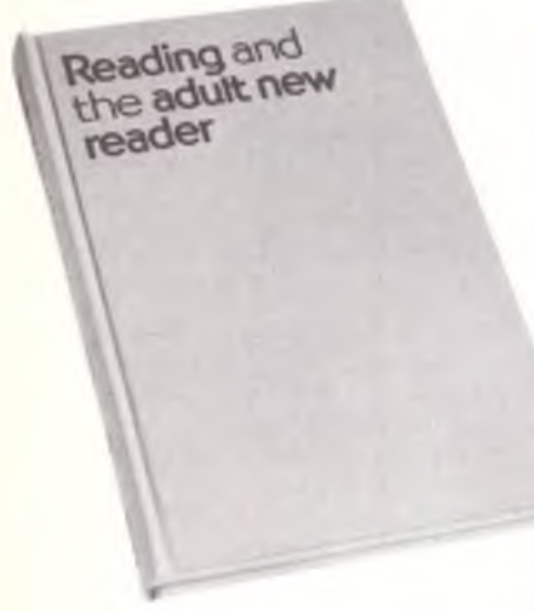

\section{Reading and the Adult New Reader}

\section{Helen Huguenor Lyman}

A reliable guide for librarians, teachers, editors, library science professors, and students who are involved in the evaluation, uses, and creation of materials for adult new readers. The focus is on the readability of materials in collections for such readers; it organizes the theories of readability for practical application as well as describing the reading interests of minority group members.

Lyman's method of identifying works suitable for adult new readers extends the relevance of this book to the entire field of adult education.

Major topics that are discussed include reading services; trends in society; beliefs, attitudes and values affecting readers and reader groups: reading collections for the adult reader; evaluation of reading materials; and implications of these topics and factors for library service. This work points out a direction for bringing the adult reader and library resources together.

272 pages Cloth LC 76-44431 ISEN 0-8389-0228-6 $\$ 15.00$

\section{Other titles of interest:}

\section{Literacy and the Nation's Libraries \\ Helen H. Lyman}

At the heart of this work is the procedure to be followed by public libraries in developing their programs to serve the illiterate. This procedure consists of bringing the library to the attention of concerned organizations, assessing library resources and com munity needs, lesting and adopting the program, and evaluating it. Tasks in the design of each program are discussed.

Literacy and the Nation's Libraries has the additional aim of educating librarians to the general problem of illiteracy in the United States and its remediation. In keeping with its character as a manual the work lists sample programs, funding sources, and kinds of material needed for the literacy collection.
242 pages
Cloth
LC 77-4450
ISBN 0-8389-0244-8

$\$ 12.50$

Order Department

American Library Association

50 East Huron Street

Chicago, Illinois 60611

\section{Library Materials in Service to the Adult New Reader Helen Huguenor Lyman}

Published here as a comprehensive report, from the background of the research through to the principal recommendations, this volume not only establishes criteria for evaluating reading materials, but also provides a multitude of information about the new literate and their use of the media. This study will guide librarians, community workers, teachers, publishers, and editors in both creating and selecting literature for these newcomers to the reading public.
648 pages
LC 72-11668
Paper
ISBN 0-8389-0147-6 (1973)
$\$ 10.00$

\section{Information for the Community}

Joseph C. Donohue and Mantred Kochen, editors

This book is the first comprehensive treatment of community information and referral (I \& R) centers - those agencies that act as contact points between people with problems and the services that are needed to help with these problems. It analyzes the needs that gave rise to the many organizations now providing I \& $R$ services, and describes some approaches that have succeeded and some that have failed.
294 pages
Cloth LC 75-40168
ISBN 0-8389-0208-1
$\$ 10.00$

\section{Information for Everyday Survival: What You Need and} Where to Get It

Priscilla Gotsick of the Appalachian Adulf Education Center

Presents an annotated list of free and inexpensive materials arranged under such basic calegories as aging, children, free time, and housing. Some sample subheadings are abortion, getting a job, personal finance, and remodeling a home. Titles, descriptions, and sources of each item are arranged in a tabular format to facilitate identification. The titles were selected for readability, and the reliance on booklets keeps purchasing costs low.

400 pages Paper LC 76-13554 ISEN 0-8389-0211-1 \$10.00 
are evident in his publications, ranging from Africana to automation and scholarly publishing in Southeast Asia.

Herbert F. Johnson has been named the new director of libraries at Emory University, effective July 1, 1978. The director is responsible for operation of the Woodruff Library for Advanced Studies, the Candler Library, and the Guy Chemistry Library, and a staff of twenty-seven professional librarians. He is also responsible for coordinating library activities with several independently operated professional school libraries. Total collections for the university number 1.4 million vol-

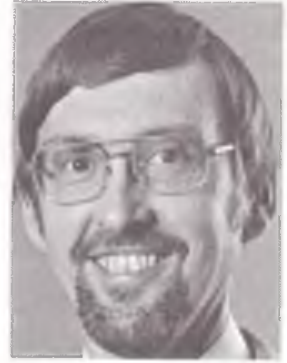

Herhert $F$. Johnson umes, 625,000 microforms, 275,000 manuscripts, and more than 14,000 subseriptions. Emory is a member of the Association of Research Libraries and SOLINET.

Johnson has been librarian of Oberlin College and professor of library science since 1971. In that position he has been responsible for the operation of the main library, three branch libraries, the audiovisual center, and the Oberlin Public Library.

During his tenure at Oberlin, Johnson was instrumental in the interior planning of the Seeley G. Mudd Learning Center, described by Interiors magazine as a "library alive and inviting" and by Keyes Metcalf as one of the most functional libraries of recent years. Two building projects were completed under his direction, the learning Center and the Clarence Ward Art Library, and a third project, renovation of Oberlin Public Library space in Carnegie Library, was planned.

A hallmark of the Johnson administration has been an active staff development program, featuring series of visits by leaders from the library and information fields and an exchange of music librarians with the County Cornwall Library System. Johnson has been host administrator for six interns under the Mellon/ACRL management intern program in the past four years.

Oberlin was one of the first Ohio libraries to go on-line with OCLC and had the largest Dewey collection of OCLC participants until the decision to change to the LC classification system and divide the catalog was made, coincidental with moving to the new building.

Johnson long has been an advocate of interlibrary cooperation, which is reflected in Oberlin's membership in INFO, one of Ohio's multicounty cooperatives, in the Cleveland Area Metropolitin Library System (CAMLS), and in Art Research Libraries of Ohio (ARLO). He has served as chairman, since its inception in October 1976, of the Ohio Multitype Inter-library Cooperation Committee (OMICC) of the State Library Board of Ohio. The fifteen-member committee has members representing several statewide multitype interlibrary cooperation programs that have been endorsed by each library association, the State Library Board, the Board of Regents, and the Ohio Department of Education. OMICC's draft program was completed in March 1978 for distribution and comment in the state prior to completion of a final draft later this year. Johnson also has been serving as a member of the steering committee for the Ohio White House Conference on Libraries and Information.

In 1975 Johnson received a CLR fellowship to study work-group organization in Swedish industry. Based in Lund, Sweden, he visited many types of libraries in Scandinavia, conducting seminars at the Swedish Library School in Boras and at Stockholm University.

Following his return from Sweden, Oberlin launched the development of an automated circulation system based on one functioning at Bucknell University. That project, using OCLC archive tapes, bar code inputting technology, and a minicomputer tied to the college's Sigma 9 computer, will be ready for operation later this year.

\section{Personalized service... Gutonatiogilly}

Faxon's automation means even more than computer speed and accuracy. It means systems designed to make Faxon customers virtual experts in subscription management.

Faxon's new SCOPE Service enables libraries to monitor price increases over a three-year period by taking price data directly from their unique personal history files stored in Faxon's computer. SCOPE is ideal for department heads and subject specialists who can make a thorough review of subscription costs as they relate to budgets prior to annual renewal.

Serials control information is also available from Faxon's computer on either punched cards or magnetic tape. Libraries with data processing capabilities will find our input precise and time-saving.

Faxon makes automation work for you .... personally

\section{EWFE. F.W. FAXON COMPANY, InC.}

Library Magazine Subscription Agency

15 Southwest Park, Westwood, Mass, 02090 Tel: 800-225-7894 (toll-free)

$617-329-3350$ (collect in Mass and Canada only) 


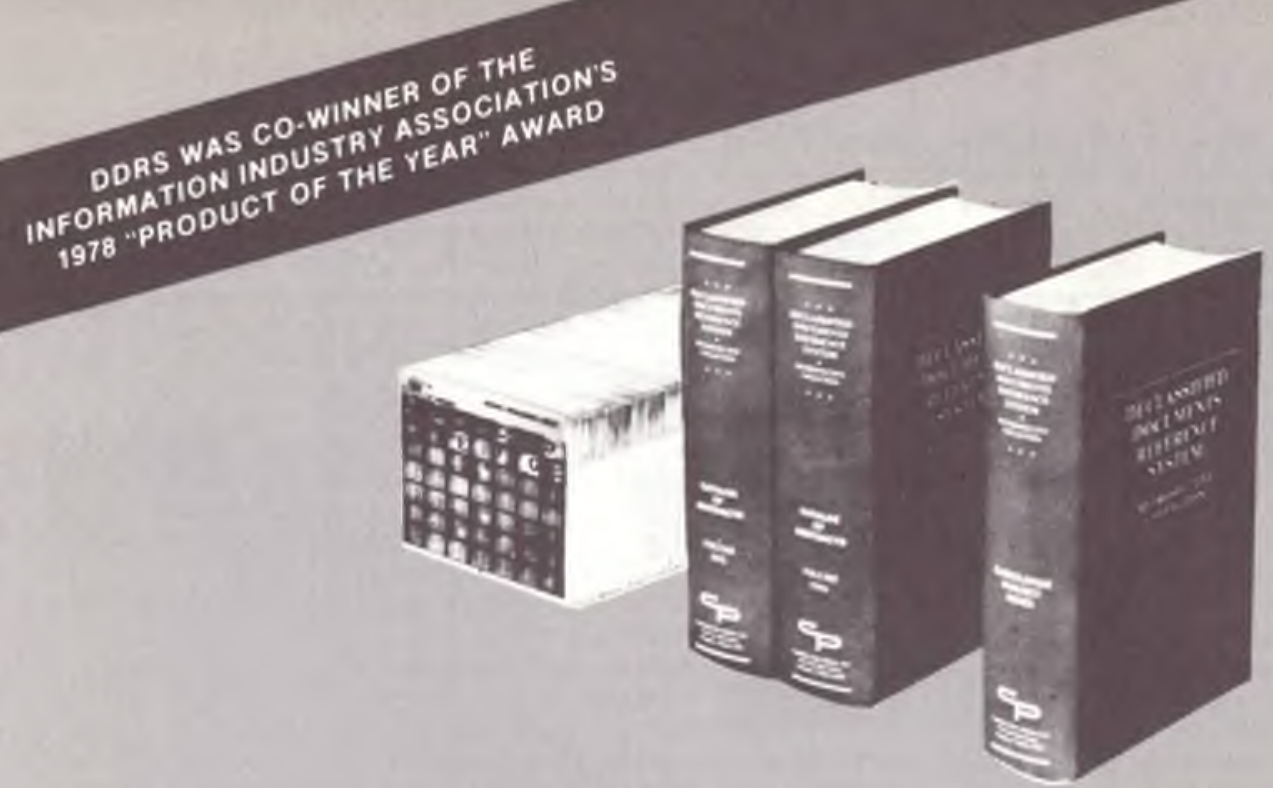

\section{THE COMPLETE RETROSPECTIVE COLLECTION AND THREE ANNUAL COLLECTIONS ARE NOW AVAILABLE FOR IMMEDIATE DELIVERY}

\section{THE RETROSPECTIVE COLLECTION}

- The full texts of 8,032 Declassified Documents are contained on 1008 Microfiche.

- Original abstracts of the documents appear in two hardcover Abstract Catalog volumes, arranged chronologically under names of issuing agencies.

- A single-alphabet Cumulative Subject Index to both the Retrospective and the 1975 Annual Collections is contained in one hardcover volume.

- Each volume contains a User's Guide and a comprehensive Glossary of intelligence terminology.

The dramatic increase in the sheer size of the system means that the Cumulative Subject Index now lists a substantial number of references to formerly classified d ocuments on the sa me subjects - thus offering unique new depths of coverage of some of the major international conflicts and diplomatic crises of the post World War II period

Included for the first time in the Retrospective Collection are special groups of documents on Alger Hiss, the Rosenbergs. and Lee Harvey Oswald (including the diary he kept while in the U.S.S. R.). Also included are declassified documents from the papers of several presidential aides and advisors such as. Chester Bowles, Clark Clifford, C.D. Jackson, General Lucius Clay and others.

It is impontant to note that none of the abstracts or microfiche copies of the documents contained in the 1975 or 1976 Annual Collections are included in the Retrospective Collection. However, all entries from the 1975 Cumulative Subject Index have been merged into a combined Cumulative Subject Index in the Retrospective set in order to provide a single source of subject access for both sets of documents.

\section{THE ANNUAL COLLECTIONS}

- THE 1975 ANNUAL COLLECTION contains 1.648 documents, abstracted on 330 pages of 4 quarterly Catalog volumes, and indexed under an average 3.2 headings in their cumulative annual Subject Index. Although early subscribers received four quarterly Indexed volumes, the first three have now been superseded by the 1975 annual cumulative volume and will be omitted from future shipment.

- THE 1976 ANNUA L COLLECTION is available in three segments (one double issue covering January-June, 1976, and two quarterlies). The number of documents included in the 1976 collection is slightly greater than that for 1975 .

- THE 1977 ANNUA L COLLECTION includes four Abstract Catalogs and a 1977 Cumulative Subject Index volume plus microfiche copies of the documents themselves.

- THE 1978 ANNUAL COLLECTION will be shipped in quarterly installments beginning in July, 1978 


\section{DECLASSIFIED DOCUMENTS REFERENCE SYSTEM}

\section{Here are excerpts from the two latest revlews of DDRS...}

RD no. 4, Summer, 1976. pp. 353-355. Reviewed by Michael 0 . Shannon, Herbert Lehman College, Bronx, New York.

"The entire system is characterized by remarkable simplicity of arrangement and ease of searching, and one hopes that it may grow in size and extent.". . "This is a major research tool to basically archival-type material and should be worth the price for any major research institution that wishes to provide first rate coverage in the fields of recent government, foreign affairs, and politics."
Groice

Association of College and Research Libraries, ALA, v. 13, no. 8 (October, 1976) unsigned.

"The catalog and separately available microfiche of the documents themselves form a complete system of information not available elsewhere, neither indexed in the Monthly Calalog nor published by the G.P.O. The catalog, indexed by a former chief of C.I.A. indexing operations, is a unique source of information about formerly secret activities, and of great value to the researcher and the large academic or public library."

\section{and from these earller reviews in the llbrary literature.}

- BOOKLIST, ALA. v. 72, No. 12 (February 15, 1976) "Reference and Subscription Books Reviews" (unsigned) pp. 875-6. "For large academic and public libraries whose patrons do extensive research in subjects in which the government may have a controlling interest, the Declassified Documents Quarterly Catalog and its Index will provide access to materials heretofore unavailable and even unknown, although their existence may have been assumed or suspected. In the expectation that future issues will appear and that coverage will expand, the Declassifted Documents Quarterly Catalog with its Cumulative Subject Index is recommended for these large libraries or any library whose patrons require access to this type of information."

- GOVERNMENT PUBLICATIONS, v. 3, No. 2 (forthcoming 1976)

The following was extracted from a review by Professor Robin Higham, Department of History, Kansas State University. Professor Higham is also author of Official Histories (1970) and an Editor of Military Affairs and Aerospace Historian. "The great advantage of what Carrollton Press is doing is that it provides the researcher and the librarian with one compact set of Declassified Documents complete with finding aids. The sooner the system is brought to the attention of scholars the better."

- SERIALS REVIEW, July/September, 1975, page 51.

Quoted below are excerpts from a review by Bernard A. Block, Documents Librarian at Ohio State University, Columbus, Ohio.

“The Carrollton Press has made a strong beginning toward developing a good collection of declassified documents, well cataloged, abstracted, and indexed. The importance of such material for historians, political scientists, and other researchers cannot be overestimated. The Declassified Documents microfiche collection and related catalogs and indexes are highly recommended for academic and public research libraries."

Your patrons will want access to the entire system -

So use this coupon to make certain your coverage will be complete.

TO: Carrollton Press, 1911 Fort Myer Drive, \#905, Arlington, Va. 22209

Please record our order for the items checked below:

$\square$ The DECLASSIFIED DOCUMENTS RETROSPECTIVE COLLECTION only, containing two volumes of Abstracts of 8032 documents. a Combined Cumulative Subject Index (which also includes entries for all documents in the 1975 Annual Collection), and 1008 microfiche containing the full text of the documents (does not include abstracts or fiche for 1975 collection). IMMEDIATE DELIVERY. $\square$ Retrospective Catalogs and Index volumes only. IMMEDIATE DELIVERY

$\square$ The 1975 ANNUAL COLLECTION, now consisting of four Quarterly Catalogs of Abstracts and one Cumulative Annual Subject Index (which superseded the first three indexes for 1975) plus microfiche. IMMEDIATE DELIVERY

$\square 1975$ Catalogs and Annual Index volume only, IM MEDIATE DELIVERY

$\square$ The 1976 ANNUAL COLLECTION, including one double issue of the Abstract Catalog (Jan-June 1976) and two Quarterly Abstract Catalogs, a Cumulative Subject Index volume, and microfiche. IMMEDIATE DELIVERY

$\square$ 1976 Catalogs and Index volumes. IMMEDIATE DELIVERY

The 1977 ANNUAL COLLECTION, consisting of microfiche copies of documents plus four Quarterly

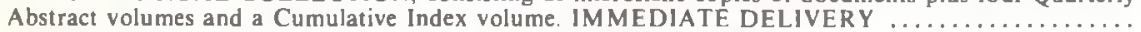
$\square 1977$ Catalogs and Index volumes only. IMMEDIATE DELIVERY

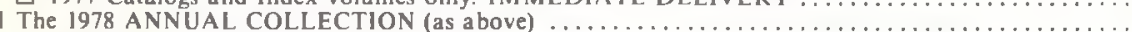

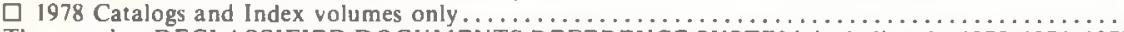

The complete DECLASSIFIED DOCUMENTS REFERENCE SYSTEM, including the 1975, 1976,1977 and 1978 Annual Collections and the RETROSPECTIVE COLLECTION. (Note the $\$ 200$ savings for ordering the full set.).

$\square$ Free brochure describing the DDRS in detail 
Interested in useful measures of library effectiveness, Johnson encouraged the implementation of user frustration studies to measure the success of students and faculty in finding library materials and in pinpointing reasons for library failure. The studies, run since 1976 , are beginning to build a longitudinal picture of library performance at Oberlin.

Prior to 1971 , Johnson served as head librarian and associate professor at Hamline L'niversity, where he planned and supervised construction of the Bush Memorial Lihrary. Long an advocate of user-oriented service, Johnson was the principal investigator at Hamline for three NSF grants to develop more responsive library service and a $3 \mathrm{M}$ grant to study the feasibility of using microfilm materials as a substitute for reserve collections.

He is an active member of the American Library Association and the American Society for Information Science. Johnson has served as chairman of the Minnesota and Northern Ohio chapters of ASIS. He is a member of the ACRL an hoc Committee to Review the 1975 College Library Standards.

A person of wide-ranging interests, Johnson is a lieutenant colonel in the U.S. Army Reserve, has served as president and treasurer of his local church, and is a member of Rotary International. A native of St. Paul, Minnesota, he received the B.A. in political science and Chinese in 1957 and the M.A. in library science in 1959 from the University of Minnesota and a certificate in Swedish

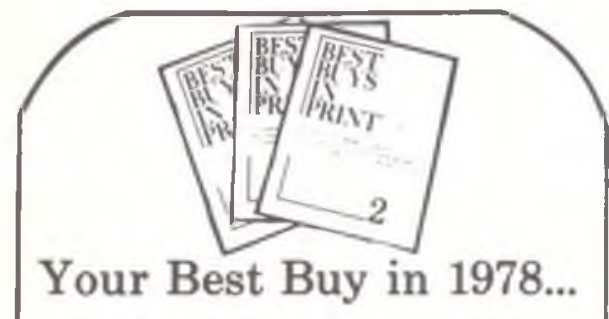

Best Buys In Print complements Books In Print, providing access to quality books at discount prices.

The second issue features the following: listings from 22 companies; 7000 titles not included in the first issue of BBIP; an asterisk preceding titles not included in the first issue (you won't duplicate efforts in checking titles you ordered in earlier isues); and a double asterisk preceding titles which have an expiration date.

A purchase of one title listed in BBIP can save the cost of your subscription to this quarterly publication, Best Buys In Print. That's a best buy!

PIERIAN PRESS

P.O. Box 1808, Ann Arbor, MI 48106 from Kursverksamheten vid Lund Universitet in 1975. He has worked as a federal librarian in Washington, D.C., and at Columbia University Libraries. He has lectured at various library schools, presented papers, and published in various forums.

DONALD W. KOEPP, university librarian at Arizona State University and former assistant university librarian for public services at Berkeley, has been named libritian for Princeton University.

Koepp, 49, hrings to his new position at Princeton broad administrative experience in university research libraries, in addition to experience as a teacher of library studies. He has served as university librarian at Arizona State since 1973; prior to that, he was university librarian at Califor-

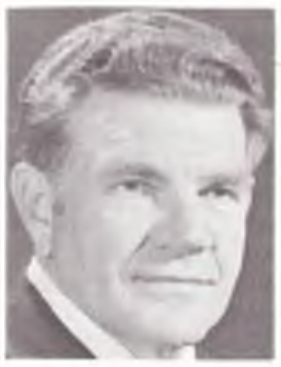

Donald $W$.

Koepp nia State University at Humboldt.

At Berkeley from 1958 to 1968 . Koepp taught in the School of Librarianship and also worked as a library analyst in Berkeley's Bureau of Public Administration. As assistant university librarian for public services (1965-68) at Berkeley, he had direct responsibility for all main library lending. general reference services, the reserve book room, the humanities graduate service, and several branch libraries, including mathematics, the sciences, and other disciplines

"Mr. Koepp is an extraordinarily fine human heing who has worked very successfully with faculty, library staff members, and students at Berkeley and most recently at Arizona," said Princeton University Provost Neil L. Rudenstine in announcing the appointment.

"At Berkeley he held one of the major administrative posts in one of the nation's largest research libraries. For his work at Arizona, he is widely regarded as having developed with great skill one of the country's most rapidly expanding research libraries, with approximately 1.5 million volumes and a staff of about 150 persons. He has been particularly responsible for strengthening the library's collection of research materials while also improving access and general services for the university's 30,000 students. I feel extremely confident that Mr. Koepp has the combination of human qualities, the understanding of universities and their research mission, and the administrative abilities to serve Princeton admirably in the years to come."

Koepp, who succeeds University Librarian Richard W. Boss, will assume his new post in early August. 
His numerous professional associations include membership on the board of directors of the Center for Research Libraries. Under his leadership, Arizona State was chosen (with Berkeley and the Massachusetts Institute of Technology) as one of three institutions in the country to participate in a major study funded by the Mellon Foundation concerning collection development in research libraries.

He was chosen for the Princeton post from among more than 100 applicants and nominees, according to Rudenstine. A fourteen-member search committee-composed of members of the faculty, library and research staffs, and the administration-consulted extensively with scholars and librarians throughout the country in its efforts to identify outstanding people for the position.

At Princeton, Koepp will be responsible for a library system of some 3 million volumes, more than 900,000 microforms, 280,000 maps, and a wide range of materials from papyri to computer tapes. With its central Harvey S. Firestone Library and eighteen specialized branches, the Princeton system constitutes one of the largest open-stack research libraries in the world.

Koepp is a 1951 graduate of the University of Wisconsin, where he also did graduate work in English literature and earned a master of library science degree (1956). He received his doctorate in library science from Berkeley in 1966 . Koepp has written a number of papers on library problems.

In addition to his literary interests, Koepp is also an amateur horticulturist and in Arizona has enjoyed mountain climbing and hiking in the desert. He and his wife, Dale, have three children, ages eighteen, twelve, and ten. They live in Tempe, Arizona.

Clifford Currie, librarian of the Ashmolean Library at the University of Oxford, one of the most important research libraries in Britain, has been appointed librarian of the Earl Gregg Swem Library at the College of William and Mary.

His appointment, approved by the board of visitors, is effective September 1.

As librarian and secretary to the Committee for the Ashmolean Library, Currie has been responsible for possibly the world's largest and most com-

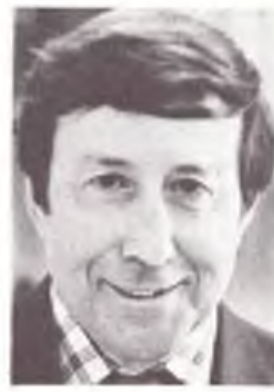

Clifford Currie prehensive library in the disciplines of ancient history, archaeology, classical studies, and ancient Near Eastern studies, including the Griffith $\mathrm{Li}-$ brary of Egyptology. A Center for Byzantine Studies is now being established in the new building of the library.

Born in Canada and educated in England, Currie holds a B.A. degree from the University of London and graduate degrees from both Oxford and Cambridge Universities, including several in law. His degrees include LL.B., Cambridge, 1950; M.A. Cambridge, 1954; M.A., Oxford, 1973; and B.C.L., Oxford, 1974. In 1950-51 he studied legal history at Harvard.

A personal interest in architecture has led Currie to involvement in planning, interior redesign, and spatial rationalization in a number of libraries. He also has a strong general interest in the history of art and in parallel developments in the structure of society and jurisprudence and technology.

In 1946 Currie became assistant librarian at Wye College, the agricultural school of the University of London. He was assistant librarian at the University of Cambridge, 1951-53, and director of libraries for the Borough of Bromley, London, $1953-59$

In 1959 he became librarian with the rank of

\section{The American Comic Strip}

I am trying to save runs of old newspapers that might otherwise be destroyed. If you should have a run or runs of bound volumes that you consider no longer worth their storage space due to transfer of your facilities to microfilm, I will be glad to pay you a fair price for them

I am a member of the Board of Directors of the San Francisco Academy of Comic Art (a division of the National Institute of Narrative Arts), a nonprofit association for the study, collection, and preservation of the American comic strip, and also act as scout for material needed by the Academy, In addition I have, since 1955, been a writer for several comic strips and panels ("The Better Half," "The Lockhorns," "Frank and Ernest," "Side Glances") and have done considerable research into the history of the genre. Obviously, I am primarily interested in major daily twentieth-century newspapers and especially those with intact Sunday comic sections. Smaller papers with only daily comics are sometimes of interest, too, if they happened to run a strip of small circulation that may not yet have been located by the academy.

I have a truck and would be able to pick up volumes personally. I hope you'll think of me should you have a run or runs of which you are willing to dispose. Contact me, Dick Hetschel, 2706 Bonaza, KS 66044; (913) 842 0130 . 
professor, directing the libraries at the Royal College of Science, the Royal School of Mines, and the City and Guilds Engineering College, three constituent libraries of the Imperial College of Science and Technology, the largest teaching and research institution within the federated University of London. He was required in nearly ten years there to coordinate the college's fourteen existing libraries, unify their catalogs, and introduce automated procedures.

Currie has served as London secretary, (196165) of the University and Research Section of the British Library Association and has been a memleer of the London-based Committee for Librarians and the Book Trade since it was begun in 1966. He also has been secretary of the Internattional Association of Technological University Libraries.

In 1968 Currie became executive director in Ottitwa, Ontario, of the Canadian Library Association. He was concerned with matters of library policy and development generally and with the profession of librarianship in Canadi. Currie joined the Ashmolean Library in 1972.

Scholar, author, lecturer, and consultant on many issues confronting libraries and librarians, Currie's work has taken him to many countries around the world. In 1966 he spent a year studying bibliographical and organizational methods in libraries, with special attention to automation in Westem European university libraries, mainly in Scandinavia, Holland, and West Germany.

During his years at the Imperial College, he served as a consultant for libraries in India, Israel, and West Africa. In 1971, he toured Australia and New Zealand research libraries.

Currie has authored a number of studies in library science. He was editor, $1962-67$, of proceedings, papers, and reprints of the International Association of Technological University Libraries. He was editor of the Canadian Library Journal, 1968-71, and serves as microforms consultint to Newspaper Archive Developments, a nonprofit division of the London Times.

Currie is currently conducting a seminar on the classical tradition in early American huilding at Oxford University.

\section{PRECIS}

The Library of Congress has made a decision not to request funding support to establish and maintain the PRECIS system for providing subject access to library materials. This decision was based in part on a project carried on in LC's Subject Cataloging Division, which applied PRECIS to 154 items cataloged by five members of the division. A brief report on the PRECIS project has been issued by IC
JEAN ARCHIBALD, associate director of the Macalester College Library, has been appointed director of the library, effective September 1, 1978. Archibald succeeds Daniel Gore who has been director since 1970. Her appointment comes following an extensive national search.

Archihald graduated from Simmons College in 1939 with a B.S. in library science. She has been an assistant librarian and faculty member at the Northfield School for Girls, East Northfield, Massachusetts; librarian and faculty

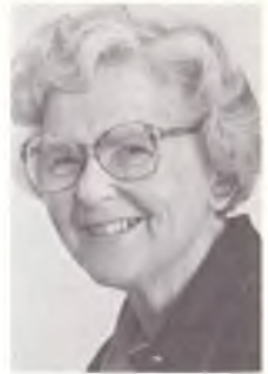

Jean Archibald member at the Mt. Hermon School for Boys, Mt. Hermon, Massachusetts; and cataloger at the library of the St. Paul Insurance Companies.

She came to Macalester in 1961 as an assistant reference librarian. In 1967 she became reference librarian and from February 1969 to July 1970 was acting librarian. Currently she holds the position of associate director and reference librarian, which includes assisting the director in the policies and administration of the library and special supervision of the reference department and the interlibrary loan operation.

Since 1976 Archibald has also held the position of adjunct associate professor and will continue to teach a course on the methods of research in govemment documents. She is a member of the Minnesota Library Association and the Minnesota Historical Society and is a director and member of the orchestra of the St. Paul Civic Symphony Association.

\section{APPOINTMENTS}

KENNETH W. BERGER-reference librarian and cataloger-DUKE UNIVERSITY, Durham, North Carolina.

JON BLAKE-assistant media librarian-UNIVERSITY OF WASHINGTON, Seattle.

SCOTT R. BullaRD-assistant head, acquisitions-DUKE UNIVERSITY, Durham, North Carolina.

Wilma R. Cipolia-head of the serials department-STATE UNIVERSITY OF NEW YORK AT BUFFALO.

Carolyn C. Cox-serials cataloger-DUKe UNIVERSITY, Durham, North Carolina.

Charles D'ANiEllo-subject librarian for history, Lockwood Library-STATE UNIVERSITY OF NEW YORK AT BUFFALO.

RiCHARD C. DAvis-manuscript catalog editor-DUkE UNIVERSITY, Durham, North Carolina.

Kay Frances DEnfeld-health sciences 
reference librarian-UNIVERSITY OF WASHINGTON, Seattle

MARIE DEVINE-instructional services librarian-UNIVERSITY OF NORTH CAROLINA AT ASHEVILLE.

JOYCE L. FARRIS - monographic cataloger -DUke UnIVERSITY, Durham, North Carolina.

Karen Gruber-editor, Union List of Serials-STATE UNIVERSTTY OF NEW YORK AT BUFFALO.

WILliam E. HANNAFORD, JR.-acquisitions librarian-MiddlebUry COLleGE, Vermont.

ARNOLD HIRSHON-assistant head, cataloging-DUke University, Durham, North Carolina.

NANCY R. JOHN-catalog librarian-UNIVERSITY OF ILLINOIS AT CHICAGO CiRCle.

Frances LAU-reference librarianMonTana STATE University, Bozeman.

ANNA MARIE KECK MCKEE-information specialist, Health Sciences Library-UNIVERSITY OF MARYLAND, Baltimore.

JEAN M. MCVOY-interlibrary loan librarian, Health Sciences Library-UNIVERSITY OF MARYLAND, Baltimore.

Carolyn Edith Mann-catalog librarian-UNIVERSITY OF WASHINGTON, Seattle.

SUSAN E. MARLESKI-information specialist, Health Sciences Library-UNIVERSITY OF MARYLAND, Baltimore.

GEORGE MATTIS-cataloger-MISSISSIPPI STATE University, Starkville.

LaURa J. Miracle-assistant reference librarian-UNIVERSITY OF ILLINOIS AT Chicago Circle.

W. BEDE Mitchell-circulation librarian-Montana STATE University, Bozeman.

PaUl J. Rinaldi-reference librarian-BosTON UNIVERSITY, Massachusetts.

KAREN S. SEIBERT-reference librarian - University of Illinois at Chicago CirCLE.

MARUORIE B. SIMON-information specialist, Health Sciences Library-UNIVERSITY OF MARYLAND, Baltimore.

JUDITH K. STERLING-assistant catalog librarian-UNiversity OF IllinoIS AT ChICAgo CirCle.

WESIEY M. TAOKA-information specialist, Health Sciences Library-UNIVERSITY OF MARYLAND, Baltimore

\section{RETIREMENTS}

Gene MCNuTT ABEL, associate director of libraries for public services, UNIVERSITY OF Tennessee, Knoxville, retired June 30 after thirty-three years of service.

Teresa Chambers, head, science and technology reference department, CALIFORNiA STATE UNIVERSITY, Long Beach, has retired after nine years of service.
VIRGINIA H. INGRAM, catalog librarian at the John W. Brister Library, MEMPHIS STATE UNIVERSITY, Tennessee, retired June 30 after twelve years of service.

John P. Waggoner, JR., associate university librarian, retired from DUKE UNIVERSITY, Durham, North Carolina, on August 31, after thirty-two years of service.

อี

\section{Circulation Task Force}

METRO, one of nine regional councils registered by the New York State Education Department (Larger New York City Metropolitan Area), has formed a Task Force on Small Libraries Circulation Control Systems. Its charge is to investigate circulation systems that are being used by smaller libraries across the United States and Canada and to develop a strategy for planning, funding, and making available a system that will be effective and practical for their relatively small budgets.

Anyone interested in this project please write to Tad G. Kumatz, Assistant Director, Pratt Institute Library, Brooklyn, NY 11205.

\section{Out of Stock? Back Orders?}

If your wholesaler has long delays in completing "out of stock" and "back orders", why not try the firm that specializes in this area. Current imprints are easy to deliver but it takes a personalized, specialized attention to give you reliable service on back list or other hard-toget items.

At Book House we call it "Con. cerned Service" and it works every day for a growing clientele including academic libraries just like yours.

- Call 517-849-2117 Collect -

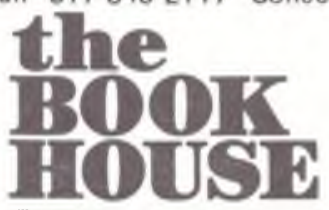

SINCE 1942

JOBBERS SERVING LIBRARIES

WITH ANY BOOK IN PRINT

200 WEST CHICAGO STAEET

JONESVILLE, MICHIGAN 49250 